\title{
Dimensioning metallic iron beds for efficient contaminant removal
}

$$
\text { Noubactep C. }{ }^{(\mathrm{a}, \mathrm{c})} \text {, Caré S. }{ }^{(\mathrm{b})}
$$

(a) Angewandte Geologie, Universität Göttingen, Goldschmidtstraße 3, D - 37077 Göttingen, Germany.

(b) Université Paris-Est, Laboratoire Navier, Ecole des Ponts - ParisTech, LCPC, CNRS, 2 allée Kepler, 77420

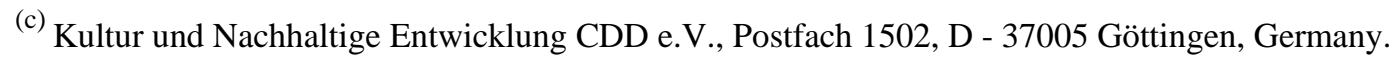

\section{Abstract}

9 Remediation of contaminated groundwater is an expensive and lengthy process. Permeable reactive barrier of metallic iron $\left(\mathrm{Fe}^{0} \mathrm{PRB}\right)$ is one of the leading technologies for groundwater remediation. One of the primary challenges for the $\mathrm{Fe}^{0} \mathrm{PRB}$ technology is to appropriately size the reactive barrier (length, width, $\mathrm{Fe}^{0}$ proportion and nature of additive materials) to enable sufficient residence time for effective remediation. The size of a given $\mathrm{Fe}^{0} \mathrm{PRB}$ depends mostly on accurate characterization of: (i) reaction mechanisms, and (ii) site-specific hydrogeologic parameters. Accordingly, the recent revision of the fundamental mechanisms of contaminant removal in $\mathrm{Fe}^{0} / \mathrm{H}_{2} \mathrm{O}$ systems requires the revision of the $\mathrm{Fe}^{0} \mathrm{PRB}$ dimensioning strategy. Contaminants are basically removed by adsorption, co-precipitation and size exclusion in the entire $\mathrm{Fe}^{0}$ bed and not by chemical reduction at a moving reaction front. Principle calculations and analysis of data from all fields using water filtration on $\mathrm{Fe}^{0}$ bed demonstrated that: (i) mixing $\mathrm{Fe}^{0}$ and inert additives is a prerequisite for sustainability, (ii) used $\mathrm{Fe}^{0}$ amounts must represent 30 to 60 vol-\% of the mixture, and (iii) $\mathrm{Fe}^{0}$ beds are deep-bed filtration systems. The major output of this study is that thicker barriers are needed for long service life. $\mathrm{Fe}^{0}$ filters for save drinking water production should use several filters in series to achieve the treatment goal. In all cases proper material selection is an essential issue. Keywords: Drinking water, Inert materials, Iron filter, Multi-filtration, Zerovalent iron. 
27 Packed beds with metallic iron $\left(\mathrm{Fe}^{0}\right)$ are currently used as contaminant mitigating agent in several contexts including groundwater remediation, wastewater treatment and drinking water production [1-4]. $\mathrm{Fe}^{0}$-based materials are used in particular (i) as reducing agents in permeable reactive walls [5-8], and (ii) as reagents to assist biofiltration in household filters $[3,9,10]$. The fundamental process responsible for contaminant removal in both contexts is necessarily the oxidative dissolution of $\mathrm{Fe}^{0}$ (iron corrosion) which may be coupled with contaminant reduction (reactive walls) or the subsequent precipitation of iron hydroxides which may be coupled with contaminant adsorption and co-precipitation (household filters). Adsorption, co-precipitation and chemical transformations (oxidation and/or reduction) are not mutually exclusive [11-13]. It is obvious that in household filters and reactive walls, a synergy between these three processes is responsible for expected and observed decontamination. Moreover, these processes proceed in the inter-granular porosity of the packed beds which are made up of $\mathrm{Fe}^{0}(100 \%)$ or a mixture of $\mathrm{Fe}^{0}$ and an inert material (e.g. gravel, pumice, sand) [2,14]. Because of the volumetric expansive nature of the process of iron corrosion [15], the porosity of the filtrating systems certainly decreases with increasing service life, possibly yielding complete permeability loss system (filter clogging) [16,17]. The filling of the pore volume by corrosion products is necessarily coupled with improved size exclusion capacity. Therefore, a fourth mechanism for decontamination in packed $\mathrm{Fe}^{0}$ beds is identified.

The very recent concept that adsorption, co-precipitation and size exclusion are the fundamental mechanisms of aqueous decontamination in $\mathrm{Fe}^{0}$ packed beds [13] is yet to be discussed in the scientific literature. The two main objectives of this communication are (i) to give some arguments supporting the new concept, and (ii) to enumerate some consequences for the further development of the iron filtration technology. In this effort a particular 
attention is paid to filter dimensioning or bed sizing. For the sake of clarity, the presentation will start with the short history of $\mathrm{Fe}^{0}$ for reactive walls and household filters.

\section{$2 \quad$ Metallic iron for reactive walls}

The $\mathrm{Fe}^{0}$ reactive wall technology is one aspect of the materialization of the original idea of McMurty and Elton [18] that a passive design "using natural groundwater flow and a treatment media" can "capture or treat the contaminants without the need for regeneration or replacement”. With the publication of this innovative concept in August 1985, an ongoing effort for efficient reactive materials for permeable reactive barriers started. In 1990, Gillham and his colleagues fortuitously found that corroding $\mathrm{Fe}^{0}$ (reductively) eliminated aqueous trichloroethylene [19]. This discovery was the starting point of remediation with elemental metals. Elemental metals (e.g. $\mathrm{Al}^{0}, \mathrm{Fe}^{0}, \mathrm{Zn}^{0}$ and bimetallics) are now recognized as competent alternatives for remediation of groundwater that is contaminated with reducible substances $[8,20]$.

Currently, however, $\mathrm{Fe}^{0}$ has exceeded all expectations because non-reducible substances have been quantitatively removed as well. For example, aqueous $\mathrm{Zn}^{\mathrm{II}}$ which is thermodynamically non-reducible by $\mathrm{Fe}^{0}$ has been efficiently removed [21]. The results of Morrison et al. [21] attested the synergic effects of removal mechanisms as the investigated systems also contained $\mathrm{Mo}^{\mathrm{VI}}$ and $\mathrm{U}^{\mathrm{VI}}$. $\mathrm{Mo}^{\mathrm{VI}}$ and $\mathrm{U}^{\mathrm{VI}}$ could be reduced to less soluble species. Furthermore, $\mathrm{Mo}^{\mathrm{VI}}$ known for its poor adsorptive capability onto iron oxides at $\mathrm{pH}>5[22,23]$ was quantitatively removed, suggesting that improved size exclusion might had been effective.

The concept that contaminants are fundamentally removed by adsorption and co-precipitation is consistent with many experimental observations which remained non-elucidated by the reductive transformation concept $[11,12]$. Although researchers are continuing to maintain the validity of the latter concept [24-26], the new concept was validated $[27,28]$ and has been independently verified [29,30]. As a matter of course the concept of adsorption/coprecipitation (and size exclusion for packed bed) should have been challenged by researchers 
working on remediation in $\mathrm{Fe}^{0} / \mathrm{H}_{2} \mathrm{O}$ systems. The motivation of using $\mathrm{Fe}^{0}$ at household level corroborates the validity of the adsorption/co-precipitation/size exclusion concept.

\section{$3 \quad$ Metallic iron for household filters}

While using slow sand filtration for water treatment in rural Bangladesh, it was observed that the filter efficiency for arsenic removal depends on the iron content of natural waters. Arsenic was readily removed from Fe-rich natural waters. Accordingly, $\mathrm{Fe}^{0}$ is used "to provide a constant input of iron (soluble or surface precipitate) for groundwater low in soluble iron” [32]. The very efficient resulting filter for As removal was the 3-Kolsi filter [10,33]. A typical 3-Kolsi filter contained a layer of about $3 \mathrm{~kg} \mathrm{Fe}^{0}\left(100 \% \mathrm{Fe}^{0}\right)$. However, the 3-Kolsi filter was not sustainable as it clogged after some 8 weeks of operation [3,34].

The remarkable efficiency of 3-Kolsi filters has prompted researchers to further develop the system for improved sustainability [9,10,31,34-37]. The best product is the SONO arsenic filter in which the $100 \% \mathrm{Fe}^{0}$ layer is replaced by a proprietary porous $\mathrm{Fe}^{0}$-based material (termed as Composite Iron Material - CIM) [32,33]. The two most important features of CIM are: (i) its porosity and (ii) its low content of $\mathrm{Fe}^{0}$. In consequence, two opposite effects may be observed: (i) the porous structure of the CIM induces a larger reactive surface compared to non-porous $\mathrm{Fe}^{0}$ particle (or compact $\mathrm{Fe}^{0}$ ); the internal porosity could be regarded as magazine for in-situ generated iron corrosion products and (ii) less initial $\mathrm{Fe}^{0}$ is used compared to compact $\mathrm{Fe}^{0}$ particle. The former effect (larger reactive surface) is well-documented as tool to improve $\mathrm{Fe}^{0}$ efficiency and is the rationale for using nano-scale $\mathrm{Fe}^{0}$ for water treatment [38]. The latter effect (less initial $\mathrm{Fe}^{0}$ ) could not improve $\mathrm{Fe}^{0}$ efficiency in term of $\mathrm{Fe}^{0}$ reactivity but is known as tool to delay or avoid porosity loss [39-41]. of the filter system, but not the second. These observations suggest that the $100 \% \mathrm{Fe}^{0}$ layer in the 3-Kolsi filter was the major reason for its too short service life. Leupin and Hug [35] have considerably reduced the proportion of $\mathrm{Fe}^{0}$ (1.5 $\mathrm{g} \mathrm{Fe}^{0}$ for $60 \mathrm{~g}$ sand). More recently, Gottinger [42] demonstrated in a 
102 pilot study that a volumetric mixture $\mathrm{Fe}^{0}$ :sand of 30:70 was very efficient for water treatment 103 at a small community level.

104 It is important to notice that household $\mathrm{Fe}^{0}$ filters primarily treat water of unknown 105 composition. Design efforts are focused on keeping filter permeability. Available filters were 106 designed for As removal but SONO filters have efficiently removed several other chemicals 107 and pathogens $[32,43,44]$. It is obvious that $\mathrm{Fe}^{0}$-based filters regarded as " $\mathrm{Fe}{ }^{0}$ assisted sand 108 filtration” are not designed to chemically reduce any contaminant. Even arsenics for which 109 the majority of household filters were designed is removed by adsorption, co-precipitation 110 and size exclusion, although $\mathrm{As}^{\mathrm{V}}$ reduction to $\mathrm{As}^{\mathrm{III}}$ and $\mathrm{As}^{0}$ is thermodynamically favorable $111([3,45]$ and references therein).

112 A typical SONO filter contains 5 to $10 \mathrm{~kg}$ of porous CIM (CIM: 92 - 94 \% Fe, 4 - 5 \% C, 1 - 2 $113 \% \mathrm{SiO}_{2}, 1-2 \% \mathrm{Mn}, 1-2 \% \mathrm{~S}, \mathrm{P}$ ) and may function for up to 11 years while filtering waters 114 containing up to $1000 \mu \mathrm{g}$ As/L. It is important to notice that only a fraction of the 92 - $94 \%$

115 Fe in SONO filters is in metallic form $\left(\mathrm{Fe}^{0}\right)$ and could undergo volumetric expansion. 116 Therefore, learning from SONO filters to design efficient $\mathrm{Fe}^{0}$ beds consists in reducing the 117 proportion of $\mathrm{Fe}^{0}$ and create place for in-situ generated iron corrosion products. Prior to 118 discuss an efficient designing tool, an overview of current design options to limit the impact 119 of fouling in $\mathrm{Fe}^{0} \mathrm{PRB}$ will be given.

\section{Current design approach to limit $\mathrm{Fe}^{\mathbf{0}}$ PRB clogging}

$121 \mathrm{Fe}^{0}$ PRBs are currently believed to create redox conditions for contaminant degradation or 122 immobilization [2]. Accordingly, the precipitation of iron corrosion products and other 123 secondary minerals is regarded as perturbing side effect yielding reactivity and porosity loss $124[2,14,16,17]$. Accordingly, the design of a PRB requires profound knowledge of local water 125 flow velocity (residence time), aquifer porosity, influent contaminant concentration. 126 Additionally, the contaminant degradation rate by used $\mathrm{Fe}^{0}$ is usually estimated in laboratory 127 and pilot studies and used to size the PRB. Sizing aspects include the amount of $\mathrm{Fe}^{0}$ to be 
used and the thickness of the bed (filter or wall). The first problem with this approach is that used $\mathrm{Fe}^{0}$ media can not be each other compared in reactivity as there is no standard procedure 130 to this end [46].

131 Recently, Li and Benson [2] identified and discussed five relevant strategies to limit the

132 clogging of $\mathrm{Fe}^{0}$ PRBs: (i) pea gravel equalization zones up gradient and down gradient of the 133 reactive zone to equalize flows (strategy 1), (ii) placement of a sacrificial pre-treatment zone 134 upstream of the reactive medium (strategy 2), (iii) $\mathrm{pH}$ adjustment (strategy 3), (iv) use of 135 larger $\mathrm{Fe}^{0}$ particles (strategy 4), and (v) periodic mixing of the $\mathrm{Fe}^{0}$ to break up and redistribute 136 secondary minerals (strategy 5).

137 In the light of the concept that contaminants are basically removed by adsorption, co138 precipitation and size exclusion, the following comments can be made on the five strategies. 139 Strategy 1 necessarily has a double function as quantitative contaminant removal may occur 140 in the equalization zones. The same remark is valid for strategy 2 as this study shows that 141 reactive zones with $100 \% \mathrm{Fe}^{0}$ are not sustainable. Strategy 3 is recommended because iron 142 corrosion is sustained by $\mathrm{FeS}_{2}$ dissolution (or $\mathrm{H}^{+}$production). Accordingly, $\mathrm{FeS}_{2}$ should be 143 regarded as useful reactive additive $\left(\mathrm{Fe}^{0} / \mathrm{FeS}_{2}\right.$ system or $\mathrm{Fe}^{0} / \mathrm{FeS}_{2} /$ sand system). Hereby, care 144 should be taken that the added proportion of $\mathrm{FeS}_{2}$ don't induce a $\mathrm{pH}$ shift below a value of 145 5.5. In fact, if the final $\mathrm{pH}<5.5$ the Fe solubility is increased and the effluent may exhibit too 146 high Fe concentration. On the other hand, if dissolve Fe is transported away from the reactive 147 zone, the bed porosity will increase and the filtration efficiency will decrease. Another 148 positively tested reactive additive is $\mathrm{MnO}_{2}[29,47,48] . \mathrm{MnO}_{2}$ reductive dissolution is driven 149 by $\mathrm{Fe}^{\mathrm{II}}$ from $\mathrm{Fe}^{0}$ oxidation, sustaining $\mathrm{Fe}^{0}$ dissolution is beneficial for the decontamination 150 process. Strategy 4 will be effective only at certain sites depending on the extent of 151 contamination. In fact, larger size $\mathrm{Fe}^{0}$ means larger pore space and poorer size exclusion.

152 Finally, Strategy 5 can be rendered superfluous by a proper bed design. 
153 The approach based on the concept that contaminants are removed by adsorption, co154 precipitation and size exclusion has the advantage that only iron corrosion with site-specific

155

156 water or relevant model water has to be characterized for proper barrier design. Accordingly, an aggressive groundwater will rapidly corrode iron, rendering a thin wall satisfactorily. For less aggressive waters a thicker wall is necessary to enable completed contaminant removal by multi-filtration (see discussion section). The same systematic can be applied to $\mathrm{Fe}^{0}$ media of various reactivity. The less reactive a material in a groundwater, the thicker the reactive barrier. Therefore, the selection of the most appropriate $\mathrm{Fe}^{0}$ material at each site is a key issue for wall or generally bed efficiency. The next section is focused on better designing $\mathrm{Fe}^{0}$ beds.

\section{$5 \quad$ Designing $\mathrm{Fe}^{0}$ beds}

The presentation above suggests that $\mathrm{Fe}^{0}$ bed design must be based on the available pore volume for volumetric expansion of corroding iron. Accordingly, for a given bed size replacing a portion of reactive iron by an inert material is the first tool to extend filter service life. The very first additive material in this regard is a non-porous material as quartz (0\% porosity). The next step could consist in partly or totally replacing quartz by porous materials like sandstone (up to $40 \%$ porosity) or pumice (up to $90 \%$ porosity). In each case a critical $\mathrm{Fe}^{0}$ :additive ratio must exist for which bed porosity is lost upon $\mathrm{Fe}^{0}$ depletion as illustrated below.

\subsection{Sustaining $\mathrm{Fe}^{0}$ bed reactivity by addition of inert materials: Bed design}

A random packed $\mathrm{Fe}^{0}$ bed of identical spheres is considered. The initial bed porosity $\Phi_{0}$ has a fundamental value of $36 \%$ [49]. In other words, regardless from the actual dimension of the bed, $64 \%$ of the bed volume $\mathrm{V}$ is filled by dense $\mathrm{Fe}^{0}$ and $36 \%$ is available as inter-granular pore space for corrosion products. It can be noticed that the compactness $\mathrm{C}$ of the granular medium is $\mathrm{C}=1-\Phi_{0}=\mathrm{V}_{\text {initial Fe }} / \mathrm{V}=0.64$ where $\mathrm{V}_{\text {initial } \mathrm{Fe}}$ is the initial volume of iron. If a volumetric fraction of $\mathrm{Fe}^{0}$ is replaced by non-porous quartz (with the same particle diameter), $36 \%$ of the bed volume is still available for corrosion products but more $\mathrm{Fe}^{0}$ will corrode 
179 before the bed porosity decreases to zero (Fig. 1). Calculations could enable the identification

180 of critical $\mathrm{Fe}^{0}$ :additive ratios. Two hypothetical examples will be used here for illustration: (i)

181 a rectangular reactive wall, and (ii) a cylindrical household filter.

182 The dimensions of the demonstration reactive wall in Borden (Ontario, Canada) are used for 183 the hypothetical reactive wall [5]. The dimensions of the wall were $5.5 \times 1.6 \times 2.2 \mathrm{~m}(\mathrm{l} \times \mathrm{w} \times$ $184 \mathrm{~h}$ ), giving a volume $\mathrm{V}=19.36 \mathrm{~m}^{3}$. For the hypothetical cylindrical household filter the 185 dimensions of field columns used by Westerhoff and James [49] are adopted. The columns 186 had a total capacity or volume $\mathrm{V}=4.022 .10^{-3} \mathrm{~m}^{3}(4.022 \mathrm{~L})$ : diameter $7.5 \mathrm{~cm}$ and height 91 $187 \mathrm{~cm}$.

188 The filling of the bed porosity by iron corrosion products can be estimated from a simplified modeling (Fig. 1) based on the following assumptions:

190 (i) uniform corrosion: the diameter reduction of the particle is the same for all the $\mathrm{Fe}^{0}$ 191 particles,

192 (ii) iron corrosion products are fluid enough to progressively fill available pore space.

193 Assuming that the coefficient of volumetric expansion $(\eta)$ of the iron corrosion products is:

$$
\eta=\mathrm{V}_{\text {oxides }} / \mathrm{V}_{\mathrm{Fe}}
$$

195 where $\mathrm{V}_{\text {oxides }}$ is the volume of the iron corrosion products and $\mathrm{V}_{\mathrm{Fe}}$ the volume of parent $\mathrm{Fe}^{0}$. 196 The surplus volume of the iron corrosion products contributing to porosity loss is V' ${ }_{\text {oxides. }}$ Per definition $\mathrm{V}^{\text {' }}$ oxides is the difference between the volume $\mathrm{V}_{\text {oxides }}$ of iron corrosion products and 198 the volume $\mathrm{V}_{\mathrm{Fe}}$ of parent $\mathrm{Fe}^{0}$. $\mathrm{V}^{\text {, }}$ oxides is given by $\mathrm{Eq} .2$ :

$$
\mathrm{V}^{\prime}{ }_{\text {oxides }}=(\eta-1) * \mathrm{~V}_{\mathrm{Fe}}
$$

200 Assuming that the bed is clogged when the volume $\mathrm{V}^{\text {, }}$ oxides is equal to the initial inter granular 201 voids $\left(\Phi_{0} . \mathrm{V}\right)$, the volume $\mathrm{V}_{\mathrm{Fe}}$, clogging of the consumed iron leading to clogging of the bed is 202 then estimated by:

$$
\mathrm{V}_{\mathrm{Fe}, \mathrm{clog} \text { ging }}=\frac{\Phi_{0} \cdot \mathrm{V}}{\eta-1}
$$


In this case (Eq.3), the volume $\mathrm{V}_{\mathrm{Fe}}$, clogging of the consumed iron is inferior to the initial

205 volume of dense $\mathrm{Fe}^{0}$. It means that clogging appears before depletion of Fe. It can be noticed 206 that, in some cases, the initial volume of iron may be too low so that there is no clogging and

207 the bed porosity is not completely filled by iron corrosion products.

208 The residual porosity $\Phi_{\mathrm{r}}$ defined by $\Phi_{\mathrm{r}}=\mathrm{V}$ residual voids $/ \mathrm{V}$ is evaluated by Eq. 4 :

$$
\Phi_{\mathrm{r}}=\Phi_{0}-(\eta-1) \cdot \frac{\mathrm{V}_{\text {consumedFe }}}{\mathrm{V}}
$$

where $\mathrm{V}_{\text {consumedFe }}$ is the volume of Fe which is consumed. When the clogging appears before

211 depletion of $\mathrm{Fe}^{0}$, the volume $\mathrm{V}_{\text {consumedFe }}$ is given by the equation 3 and the residual porosity is 212 equal to $\Phi_{\mathrm{r}}=0$. When there is no clogging, the volume $\mathrm{V}_{\text {consumedFe }}$ is equal to the initial volume 213 of Fe and there is residual porosity $\left(\Phi_{\mathrm{r}} \neq 0\right)$.

214 These calculations allow the evaluation of the efficiency of the bed (reactive wall or filter) 215 related to the possible clogging. Two cases are discussed in the following.

\section{$216 \quad 5.2 \quad$ Case of a $\mathbf{1 0 0} \% \mathrm{Fe}^{0}$ bed}

217 Considering that the density of $\mathrm{Fe}^{0}$ is $7,800 \mathrm{~kg} / \mathrm{m}^{3}$, the $12.4 \mathrm{~m}^{3}$ (64\% of the total volume) 218 available in the hypothetical reactive wall (Tab. 1) can be filled by $96,645 \mathrm{~kg}$ of $\mathrm{Fe}^{0}$. The 219 calculations in Tab. 2 demonstrated that from this $\mathrm{Fe}^{0}$ amount only a maximum of 50,336 $\mathrm{kg}$ 220 can be oxidized to yield porosity loss (no residual porosity, $\Phi_{\mathrm{r}}=0$ ). The weight proportion of 221 consumed $\mathrm{Fe}^{0}$ ranges between $10.4 \%$ and $52.1 \%$ when the main corrosion products are $\mathrm{Fe}(\mathrm{OH})_{3} \cdot 3 \mathrm{H}_{2} \mathrm{O}$ (ferrihyrite) or $\mathrm{Fe}_{2} \mathrm{O}_{3}$ (hematite) respectively, showing that $100 \% \mathrm{Fe}^{0}$ reactive walls are pure material wastage. The calculations for the hypothetical household filter

224 demonstrated that only 2.1 to $10.5 \mathrm{~kg}$ of $\mathrm{Fe}^{0}$ will be consumed corresponding to the same 225 weight percent like for the hypothetical reactive wall.

226 Ideally, when $\mathrm{Fe}^{0}$ is mixed with quartz, a bed containing more than $52.1 \mathrm{wt}-\% \mathrm{Fe}^{0}$ of the mass 227 of $\mathrm{Fe}^{0}$ necessary to have a $100 \% \mathrm{Fe}^{0}$ bed should not be constructed because bed clogging will 228 happen and excess $\mathrm{Fe}^{0}$ will not react (material wastage). The actual $\mathrm{Fe}^{0}$ proportion will 
depend on its intrinsic reactivity and the kinetics of iron oxidative dissolution. Kinetics aspects are not considered in this study.

\subsection{Case of a volumetric $\mathrm{Fe}^{0}:$ quartz ratio of $50: 50$}

232 The calculations above suggests that only about 10.4 to $52.1 \mathrm{wt}-\% \mathrm{Fe}^{0}$ is necessary to fill the 233 pore space of a $100 \% \mathrm{Fe}^{0}$ filter regardless from the bed dimensions. In this section, the 234 calculations are made for a volumetric $\mathrm{Fe}^{0}$ :quartz ratio of 50:50. To calculate the 235 corresponding weight ratio, one should use the particle size and the densities. However, 236 because the same beds (wall and filter) are used, the bed volume occupied by 50 vol-\% is 237 necessarily one half of the value used in the pure $\mathrm{Fe}^{0}$ bed: (i) $6.20 \mathrm{~m}^{3}$ or $48,322 \mathrm{~kg}$ for the 238 wall and (ii) $1.3^{*} 10^{-3} \mathrm{~m}^{3}(1.3 \mathrm{~L})$ or $10.4 \mathrm{~kg}$ for the filter. It is evident that the $\mathrm{Fe}^{0}$ masses 239 consumed to yield bed clogging are the same as in the $100 \% \mathrm{Fe}^{0}$ case. The percent 240 consumption is then higher (more iron is consumed to obtain the same volume of iron corrosion products at $\mathrm{Fe}^{0}$ depletion, Fig. 1 and varies from $21 \%$ for $\mathrm{Fe}(\mathrm{OH})_{3} \cdot 3 \mathrm{H}_{2} \mathrm{O}$ to $100 \%$ 242 for $\mathrm{Fe}_{2} \mathrm{O}_{3}$ and $\mathrm{Fe}_{3} \mathrm{O}_{4}$.

243 The bed containing 50 vol- $\% \mathrm{Fe}^{0}$ is necessarily clogged at $\mathrm{Fe}^{0}$ depletion; no residual porosity $244\left(\Phi_{\mathrm{r}}=0\right)$. However, an ideal treatment system should keep a certain residual porosity. This is 245 particularly important for subsurface reactive barriers. To warrant a residual porosity $\left(\Phi_{\mathrm{r}} \neq 0\right)$ 246 while using a constant $\mathrm{Fe}^{0}$ amount in the bed, it appears that thicker beds have to be 247 considered. For example the amount of additive material can be increased such that the 248 resulting volumetric proportion of $\mathrm{Fe}^{0}$ is $35 \%$. Another tool to sustain $\mathrm{Fe}^{0}$ reactivity is to use 249 porous additive instead of non-porous quartz. In this way, the total volume for the storage of 250 in-situ generated iron corrosion products is increased and the residual bed porosity at $\mathrm{Fe}^{0}$ 251 depletion is warranted as will be illustrated in the next section.

\section{$252 \quad 5.4 \quad$ Lengthening $\mathrm{Fe}^{0}$ bed service life by porous additives}

When quartz particles from section 5.3 are replaced by $V_{\mathrm{PP}}$ of porous particles (with $\mathrm{V}_{\mathrm{PP}}=\mathrm{V}$ -

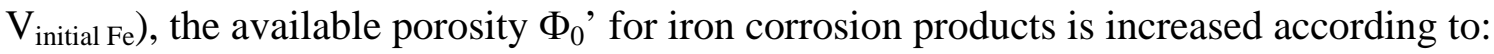




$$
\Phi_{0}{ }^{\prime}=\Phi_{0}+\varphi_{\mathrm{pp}} \cdot \mathrm{f}_{\mathrm{pp}}
$$

where $\varphi_{\mathrm{pp}}(-)$ is the critical porosity of the porous particles;

$f_{p p}(-)$ is the porous particle volume fraction (here $f_{p p}=V_{p P} / V$ ).

The volume $\mathrm{V}_{\mathrm{Fe}}$ of the consumed iron leading to clogging of the bed (Eq. 3) or the residual porosity $\Phi_{\mathrm{r}}\left(\right.$ Eq. 4) can be obtained by replacing $\Phi_{0}$ by $\Phi_{0}$ '. The calculations in Tab. 3 show that it is possible to increase the efficiency of the filtration system. More iron may be consumed and transformed into iron corrosion products before clogging. In two cases $\left(\mathrm{Fe}_{2} \mathrm{O}_{3}\right.$ and $\mathrm{Fe}_{3} \mathrm{O}_{4}$ ), a residual bed porosity is available at Fe depletion.

Figure 2 shows that replacing quartz by sandstone or more porous (or less dense) materials could further extend $\mathrm{Fe}^{0}$ bed service life. This conclusion is justified by the fact that heavier materials are less porous. However, the most important feature from Fig. 2 is that weightbased and volumetric ratios are not linearly dependent. Therefore, the description of any experimental design should comprise data on $\mathrm{Fe}^{0}$ and additives (form, density, porosity, size) and filter dimensions together with the volumetric proportion of $\mathrm{Fe}^{0}$. This procedure will enable or ease comparability of published results.

\subsection{Discussion}

The calculations above have shown that in a $100 \% \mathrm{Fe}^{0}$ bed, system clogging will occur when only about 52 wt-\% of used $\mathrm{Fe}^{0}$ is consumed. In a $50 \% \mathrm{Fe}^{0}$ bed material depletion $(100 \%$ consumption) is only possible if the corrosion products are $\mathrm{Fe}_{3} \mathrm{O}_{4}$ and $\mathrm{Fe}_{2} \mathrm{O}_{3}$ (no residual porosity). By replacing quartz by sandstone, a residual porosity $\Phi_{\mathrm{r}}$ about $12 \%$ is obtained when the corrosion products are $\mathrm{Fe}_{3} \mathrm{O}_{4}$ and $\mathrm{Fe}_{2} \mathrm{O}_{3}$. But even in these cases, crystalline $\mathrm{Fe}_{3} \mathrm{O}_{4}$ and $\mathrm{Fe}_{2} \mathrm{O}_{3}$ are the final stages of transformations which go through several more volumetric amorphous stages (e.g. $\mathrm{Fe}(\mathrm{OH})_{2}$, FeOOH). Accordingly, a volumetric ratio 50:50 should be regarded as the highest proportion of $\mathrm{Fe}^{0}$ for long-term efficiency of $\mathrm{Fe}^{0}$ beds. In the literature however, a 50:50 weight ratio is usually used based on a pragmatic approach [50]. The 
volumetric 50:50 ratio for the $\mathrm{Fe}^{0}$ :quartz mixture (quartz: $2.6 \mathrm{~kg} / \mathrm{m}^{3}$ ) corresponds to a

$281 \mathrm{Fe}^{0}$ :quartz weight ratio of 75:25. The suitability of the volumetric ratio in this context arises 282 from the fact that the expansive nature of iron corrosion is to be considered. Finally, a 283 consideration of the conditions used by O’Hannesin and Gillham [5] and Westerhoff and 284 James [50] is made.

285 O’Hannesin and Gillham [5] used only $22 \mathrm{wt}-\% \mathrm{Fe}^{0}$ in the reactive wall in Borden (Ontario 286 Canada). This proportion corresponds to less than 10 vol-\% $\mathrm{Fe}^{0}$ showing that the 287 demonstration wall at Borden is highly permeable. Accordingly, system clogging due to expansive iron corrosion is not expected because the available pore space is by far larger than the volume of iron corrosion products at $\mathrm{Fe}^{0}$ depletion. As discussed in section 4, most $\mathrm{Fe}^{0}$ 290 PRBs content a zone with $100 \% \mathrm{Fe}^{0}$. In some cases “equalization zones" and a "sacrificial 291 pre-treatment zone" exist in which $\mathrm{Fe}^{0}$ is mixed with gravel or sand. In recent barriers mixing $292 \mathrm{Fe}^{0}$ and sand is considered as a tool to save expense for $\mathrm{Fe}^{0}$ media [51]. However, the proper 293 consideration of the expansive nature of $\mathrm{Fe}^{0}$ corrosion shows that mixing $\mathrm{Fe}^{0}$ and inert 294 material is a prerequisite for long service life.

295 Westerhoff and James [50] could evidence the difficulty of performing long-term experiment 296 with $100 \% \mathrm{Fe}^{0}$ beds. A weight-base 50:50 $\mathrm{Fe}^{0}$ :sand bed could perform accurately for several 297 months (12 months). Similarly, household $100 \% \mathrm{Fe}^{0}$ filters were abandon because of rapid 298 clogging $[10,32]$. The calculations above rationalize the current renaissance of $\mathrm{Fe}^{0}$ filter 299 technology for household filters [52] and its use for small scale water facilities [42,53]. $\mathrm{Fe}^{0}$ 300 filter technology is regarded as a flexible and affordable technology, which could enable the 301 achievement of the Millenium Development Goals (MDGs) for water. This simple technology 302 could even enable to achieve universal access to safe drinking water within some few years $303 \quad[52]$.

\section{$3046 \quad$ General discussion}

\section{$305 \quad 6.1 \quad \mathbf{F e}^{\mathbf{0}}$ bed as adsorptive size-exclusion system}


The consideration of $\mathrm{Fe}^{0}$ beds as adsorptive size-exclusion systems arises from the strong adsorptive properties of in-situ generated iron corrosion products [54]. Iron is progressively corroded (uniform corrosion) in the whole bed. Contaminants are removed by adsorption, coprecipitation and size exclusion within the whole bed. Removed contaminants could be further chemically transformed (oxidized or reduced). A contaminant that is not removed in

311 the entrance zone could be removed deeper in the $\mathrm{Fe}^{0}$ bed (deep-bed filtration). This 312 behaviour is illustrated the best by simple experiments by Leupin and Hug [34]. These 313 authors performed an As removal experiment in a series of four filters. Each filter contained $1.5 \mathrm{~g}$ iron and $60 \mathrm{~g}$ sand. The system with a total of $6 \mathrm{~g}$ iron could efficiently filtered $36 \mathrm{~L}$ of an aqueous solution containing $500 \mathrm{mg} \mathrm{As/L}$. A close consideration of the filtration efficacy 316 pro filtration event showed that less than $20 \%$ (100 mg As/L) of the initial arsenic was removed during the first filtration; a much larger fraction ( $\geq 200 \mathrm{mg}$ As/L) was removed during the second filtration, arsenic removal continued during the third and fourth filtration. It is important to note that $\mathrm{Fe}^{0}$ was not depleted in the experiments and the filters were not clogged. Accordingly, further As removal occurred even though As breakthrough ([As] > 50 $\mu \mathrm{g} / \mathrm{L})$ was observed. The $\mathrm{Fe}^{0}$ weight percent of 2.4 was necessarily too low for efficient

322 filtration in a single event, but has the advantage to avoid the clogging of the filter. However, 323 this experiment demonstrated the deep-bed filtration nature of individual $\mathrm{Fe}^{0}$ beds which 324 could equally be demonstrated with four sample ports on a single bed.

325 For the further illustration of deep-bed filtration nature of $\mathrm{Fe}^{0}$ beds, Fig. 3 compares the 326 breakthrough of contaminants in a granular activated carbon (GAC) bed and a $\mathrm{Fe}^{0}$ bed. To be 327 treated, water is applied directly to the upper end and allow to flow through the packing bed 328 by gravity.

329 GAC is inert in water and the adsorption capacity is consumed only by contaminants which 330 displace $\mathrm{H}_{2} \mathrm{O}$ from adsorption sites. Accordingly, the region where contaminant adsorption 331 takes place is called the mass-transfer zone (or adsorption front). The region above the 
adsorption front is the saturated zone and the region below is the virgin zone. As a function of time, the saturated zone moves through the bed and approaches the end [54]. The adsorption bed is exhausted when no more satisfactorily decontamination is achieved.

On the contrary, in a $\mathrm{Fe}^{0}$ bed, the whole bed is available as sorption, co-precipitation and size exclusion system. A sort of “adsorption front” may exist because of increased oxidizing agent's levels in the inflowing solution. However in the whole bed $\mathrm{H}_{2} \mathrm{O}$ corrodes $\mathrm{Fe}^{0}$ producing corrosion products for efficiency contaminant removal. Contaminant removal may thus occur deeper in the $\mathrm{Fe}^{0}$ bed from the initial stage of bed service on.

\subsection{Significance for system design}

The scientific community has long been searching for common underlying mechanisms for

342 the process of contaminant removal in $\mathrm{Fe}^{0} / \mathrm{H}_{2} \mathrm{O}$ systems that provide a confidence for design 343 that is non-site-specific $[57,58]$. This was the idea behind introducing specific reaction rate constant $\left(\mathrm{k}_{\mathrm{SA}}\right)$. $\mathrm{k}_{\mathrm{SA}}$ values are regarded as a more general reactivity descriptor of contaminants

345 with $\mathrm{Fe}^{0}$. They are also believed to allow intersystem comparisons [56]. However, there are two major problems with the $\mathrm{k}_{\mathrm{SA}}$ concept: (i) it is contaminant specific, and (ii) it is based on

347 the concept of reductive transformation which is definitively not determinant for the process 348 of the removal of several contaminants.

349 While previous efforts were directed at achieving a significant body of removal rate for 350 individual contaminants in order to enable non-site specific bed design, the present study 351 suggests that site-specificity will govern material selection. For example, if contaminated 352 water is carbonate-rich, it could be advantageous to use a relative low reactive material which 353 corrodibility will be sustained by carbonates. Accordingly, if available $\mathrm{Fe}^{0}$ is classified for 354 specific conditions, treatability studies may only be required to fine-tune design criteria for 355 the optimal $\mathrm{Fe}^{0}$ bed performance.

\section{$356 \quad 7 \quad$ Concluding remarks}


This study clearly delineates the important role of volumetric expansion of corroding iron for the process of contaminant removal in $\mathrm{Fe}^{0}$ beds and the sustainability of $\mathrm{Fe}^{0}$ beds. Sustainability is primarily warrant by admixing $\mathrm{Fe}^{0}$ with non reactive additives to avoid or delay porosity loss. The characterization of $\mathrm{Fe}^{0}$ beds by the volumetric $\mathrm{Fe}^{0}$ :additive ratios and the bed sizes provide a clear starting point for the design of future laboratory, pilot, and fieldscale studies aiming at characterizing remediation $\mathrm{Fe}^{0}$ beds. This certainly has economic implications for $\mathrm{Fe}^{0}$ bed design as the use of too high $\mathrm{Fe}^{0}$ amount (e.g. $>60$ vol-\%) has to be avoided. Most importantly results will be more comparable, accelerating progress in technology development.

The most important result from the calculations of this study is that, for a given $\mathrm{Fe}^{0}$ amount, necessary for efficient decontamination at a specific contaminated site, building a thicker barrier in which iron represents a volumetric proportion of 30 to $45 \%$ is more advantageous than a thin barrier containing more than 60 vol-\% iron. A further useful tool to extend $\mathrm{Fe}^{0}$ bed service live is to use porous additives which allow avoiding/delaying bed clogging.

The installation of thicker reactive walls in the underground is certainly coupled with elevated investment costs. However, thickening the barrier is essential for barrier sustainability (deepbed filtration). For household filters and $\mathrm{Fe}^{0}$ beds in water treatment plants [42,53] the achievement of multi-filtration is an easier task as for instance, several beds could let to operate in series.

Finally, it should be highlighted that the very first reactive wall constructed at Borden (Ontario, Canada) for the demonstration of the feasibility of the new technology contained less that 10 vol-\% $\left(\mathrm{Fe}^{0}\right)$ and could never been clogged because the porosity of the system could not be filled by expansive iron corrosion products. In other words because of insufficient system analysis, the $\mathrm{Fe}^{0}$ reactive wall technology was demonstrated on a very permeable system but operating walls are necessarily less permeable. Moreover, mixing $\mathrm{Fe}^{0}$ and sand was considered as a tool to reduced $\mathrm{Fe}^{0}$ costs $[51,52]$. It is now demonstrated, that 
mixing $\mathrm{Fe}^{0}$ with inert additives is even the prerequisite for sustainability. It is hoped that the

384 huge literature on deep-bed filtration [59,60] will now be used for the further development of 385 iron wall technology.

\section{Acknowledgments}

387 Sven Hellbach (student research assistant) is acknowledged for technical assistance. The 388 manuscript was improved by the insightful comments of anonymous reviewers from 389 Chemical Engineering Journal.

\section{$390 \quad$ References}

391 [1] J.W. Lee, D.K. Cha, Y.K. Oh, K.B. Ko, S.H. Jin, Wastewater screening method for evaluating applicability of zero-valent iron to industrial wastewater, J. Hazard. Mater. 180 393 (2010), 354-360.

394 [2] L. Li, C.H. Benson, Evaluation of five strategies to limit the impact of fouling in 395 permeable reactive barriers, J. Hazard. Mater. 181 (2010) 170-180.

[3] M.I. Litter, M.E. Morgada, J. Bundschuh, Possible treatments for arsenic removal in Latin American waters for human consumption, Environ. Pollut. 158 (2010) 1105-1118.

[4] J. Bundschuh, M. Litter, V.S.T. Ciminelli, M.E. Morgada, L. Corneo, S.G. Hoyos, J. Hoinkis, M.T. Alarcon-Herrera, M.A. Armienta, P. Bhattacharya, Emerging mitigation needs and sustainable options for solving the arsenic problems of rural and isolated urban areas in Latin America e A critical analysis, Water Res. (2010) doi:10.1016/j.watres.2010.04.001.

[5] S.F. O’Hannesin, R.W. Gillham, Long-term performance of an in situ "iron wall" for 403 remediation of VOCs, Ground Water 36 (1998) 164-170.

404 [6] K.C.K. Lai, I.M.C. Lo, V. Birkelund, P. Kjeldsen, Field monitoring of a permeable 405 reactive barrier for removal of chlorinated organics, J. Environ. Eng. 132 (2006) 199-210. 
[6] D.H. Phillips, T. Van Nooten, L. Bastiaens, M.I. Russell, K. Dickson, S. Plant, J.M.E.

409 Ahad, T. Newton, T. Elliot, R.M. Kalin, Ten year performance evaluation of a field-scale zero-valent iron permeable reactive barrier installed to remediate trichloroethene contaminated groundwater, Environ. Sci. Technol. 44 (2010), 3861-3869.

[9] T.K.K. Ngai, R.R. Shrestha, B. Dangol, M. Maharjan, S.E. Murcott, Design for

sustainable development - Household drinking water filter for arsenic and pathogen treatment in Nepal, J. Environ. Sci. Health A42 (2007) 1879-1888.

[10] D. Pokhrel, B.S. Bhandari, T. Viraraghavan, Arsenic contamination of groundwater in the Terai region of Nepal: An overview of health concerns and treatment options, Environ. Int. 35 (2009) 157-161.

418 [11] C. Noubactep, Processes of contaminant removal in " $\mathrm{Fe}^{0}-\mathrm{H}_{2} \mathrm{O}$ ” systems revisited: The 419 importance of co-precipitation, Open Environ. J. 1 (2007) 9-13.

[12] C. Noubactep A critical review on the mechanism of contaminant removal in $\mathrm{Fe}^{0}-\mathrm{H}_{2} \mathrm{O}$ systems, Environ. Technol. 29 (2008) 909-920.

[13] C. Noubactep, The suitability of metallic iron for environmental remediation, Environ. Progr. (2010)DOI 10.1002/ep.10406.

[14] B.D.M. Painter, Optimization of permeable reactive barriers for the remediation of contaminated groundwater. Dissertation, Lincoln University, New Zealand (2005).

429 [16] L. Li, C.H. Benson, E.M. Lawson, Impact of mineral fouling on hydraulic behavior of 430 permeable reactive barriers, Ground Water 43 (2005) 582-596.

431 [17] L. Li, C.H. Benson, E.M. Lawson, Modeling porosity reductions caused by mineral 432 fouling in continuous-wall permeable reactive barriers, J. Contam. Hydrol. 83 (2006) 89-121. 
433 [18] D.C McMurty, R.O. Elton, New approach to in-situ treatment of contaminated 434 groundwaters, Environ. Progr. 4/3 (1985) 168-170.

435 [19] G.W. Reynolds, J.T. Hoff, R.W. Gillham, Sampling bias caused by materials used to 436 monitor halocarbons in groundwater, Environ. Sci. Technol. 24 (1990) 135-142.

437 [20] J.P. Muegge, P.W. Hadley, An evaluation of permeable reactive barrier projects in 438 California, Remediation 20 (2009) 41-57.

439 [21] S.J. Morrison, D.R. Metzler, B.P. Dwyer, Removal of As, Mn, Mo, Se, U, V and Zn 440 from groundwater by zero-valent iron in a passive treatment cell: reaction progress modelling, 441 J. Contam. Hydrol. 56 (2002) 99-116.

442 [22] S. Goldberg, S.M. Lesch, D.L. Suarez, Predicting molybdenum adsorption by soils using 443 soil chemical parameters in the constant capacitance model. Soil Sci. Soc. Am. J. 66 (2002) $444 \quad 1836-1842$.

445 [23] L. Brinza, L.G. Benning, P.J. Statham, Adsorption studies of Mo and V onto ferrihydrite, 446 Miner. Mag. 72 (2008) 385-388.

447 [24] S.-H. Kang, W. Choi, Response to comment on "Oxidative degradation of organic 448 compounds using zero-valent iron in the presence of natural organic matter serving as an 449 electron shuttle”, Environ. Sci. Technol. 43 (2009) 3966-3967.

450 [25] P.G. Tratnyek, A.J. Salter, Response to comment on "Degradation of 1,2,3451 trichloropropane (TCP): Hydrolysis, elimination, and reduction by iron and zinc”, Environ. 452 Sci. Technol. 44 (2010) 3198-3199.

453 [26] C. Noubactep, Elemental metals for environmental remediation: Learning from 454 cementation process, J. Hazard. Mater. 181 (2010) 1170-1174.

455 [27] C. Noubactep, Characterizing the discoloration of methylene blue in $\mathrm{Fe}^{0} / \mathrm{H}_{2} \mathrm{O}$ systems, $\mathrm{J}$. 456 Hazard. Mater. 166 (2009) 79-87. 
[28] C. Noubactep, A.-M.F. Kurth, M. Sauter, Evaluation of the effects of shaking intensity

on the process of methylene blue discoloration by metallic iron, J. Hazard. Mater. 169 (2009)

459 1005-1011.

[29] A. Ghauch, H. Abou Assi, A. Tuqan, Investigating the mechanism of clofibric acid

461

462

463

464

465

466

467

468

469

470

471

472

473

474

475

476

477

478

479

480

481

removal in $\mathrm{Fe}^{0} / \mathrm{H}_{2} \mathrm{O}$ systems, J. Hazard. Mater. 176 (2010) 48-55.

[30] A. Ghauch, H. Abou Assi, S. Bdeir, Aqueous removal of diclofenac by plated elemental iron: Bimetallic systems, J. Hazard. Mater. (2010), doi:10.1016/j.jhazmat.2010.05.139.

[31] A.H. Khan, S.B. Rasul, A.K.M. Munir, M. Habibuddowla, M. Alauddin, S.S. Newaz, A. Hussam, Appraisal of a simple arsenic removal method for groundwater of Bangladesh, J. Environ. Sci. Health A35 (2000) 1021-1041.

[32] A. Hussam, A.K.M. Munir, A simple and effective arsenic filter based on composite iron matrix: Development and deployment studies for groundwater of Bangladesh, J. Environ. Sci. Health A 42 (2007) 1869-1878.

[33] A. Hussam, Contending with a development disaster: SONO filters remove arsenic from well water in Bangladesh, Innovations 4 (2009) 89-102.

[34] O.X. Leupin, S.J. Hug, Oxidation and removal of arsenic (III) from aerated groundwater by filtration through sand and zero-valent iron, Wat. Res. 39 (2005) 1729-740.

[35] O.X. Leupin, S.J. Hug, A.B.M. Badruzzaman, Arsenic removal from Bangladesh tube well water with filter columns containing zerovalent iron filings and sand, Environ. Sci. Technol. 39 (2005) 8032-8037.

[36] H. Chiew, M.L. Sampson, S. Huch, S. Ken, B.C. Bostick, Effect of groundwater iron and phosphate on the efficacy of arsenic removal by iron-amended biosand filters, Environ. Sci. Technol. 43 (2009) 6295-6300.

[37] V. Tellen, G. Nkeng, S. Dentel, Improved filtration technology for pathogen reduction in rural water supplies. Water 2 (2010) 285-306. 
482

483

484

485

486

487

488

489

490

491

492

493

494

495

496

497

498

499

500

501

502

503

504

505

506

[38] C. Noubactep, S. Caré, On nanoscale metallic iron for groundwater remediation. J. Hazard. Mater. (2010) DOI: 10.1016/j.jhazmat.2010.06.009.

[39] G. Bartzas, K. Komnitsas, Solid phase studies and geochemical modelling of low-cost permeable reactive barriers. J. Hazard. Mater. (2010) doi:10.1016/j.jhazmat.2010.07.024.

[40] C. Noubactep, S. Caré, Enhancing sustainability of household water filters by mixing metallic iron with porous materials. Chem. Eng. J. (2010) DOI: 10.1016/j.cej.2010.06.012.

[41] C. Noubactep, S. Caré, F. Togue-Kamga, A. Schöner, P. Woafo, Extending service life of household water filters by mixing metallic iron with sand, Clean (2010) (Accepted manuscript \# clen.201000177).

[42] A.M. Gottinger, Chemical-free arsenic removal from potable water with a ZVI-amended biofilter. Master thesis, University of Regina (Saskatchewan, Canada) (2010) 90 pp.

[43] S. Tuladhar, L.S. Smith, SONO filter: An excellent technology for save water in Nepal. SOPHEN 7 (2009) 18-24.

[44] S. Tuladhar, Er.B. Man Shakya, A study on the performance of SONO filter in reducing different drinking water quality parameters of ground water: A case study in Ramgram municipality of Nawalparasi District, Nepal. Paper presented at the Regional Conference on Appropriate Water Supply, Sanitation and Hygiene (WASH) Solution for Informal Settlements and Marginalized Communities, Kathmandu, Nepal, May 19-21, 2010, (2010) 297-310.

[45] J.M. Triszcz, A. Porta, F.S. García Einschlag, Effect of operating conditions on iron corrosion rates in zero-valent iron systems for arsenic removal. Chem. Eng. J. 150 (2009) 431-439.

[46] C. Noubactep, T. Licha, T.B. Scott, M. Fall, M. Sauter, Exploring the influence of operational parameters on the reactivity of elemental iron materials, J. Hazard. Mater. 172 (2009) 943-951. 
[47] C. Noubactep, G. Meinrath, P. Dietrich, B. Merkel, Mitigating uranium in groundwater:

508 Prospects and limitations, Environ. Sci. Technol. 37 (2003) 4304-4308.

509 [48] D. Burghardt, A. Kassahun, Development of a reactive zone technology for simultaneous 510 in situ immobilisation of radium and uranium, Environ. Geol. 49 (2005) 314-320.

511 [49] A. Nur, G. Mavko, J. Dvorkin, D. Galmudi, Critical porosity; a key to relating physical 512 properties to porosity in rocks, The Leading Edge 17 (1998) 357-362.

513 [50] P. Westerhoff, J. James, Nitrate removal in zero-valent iron packed columns. Wat. Res. 37 (2003) 1818-1830.

[51] E. Bi, J.F. Devlin, B. Huang, Effects of mixing granular iron with sand on the kinetics of trichloroethylene reduction, Ground Water Monit. Remed. 29 (2009) 56-62.

[52] C. Noubactep, A. Schöner, P. Woafo, Metallic iron filters for universal access to safe 518 drinking water. Clean 37 (2009) 930-937.

[53] A.M. Gottinger, D.J. Wild, D. McMartin, B. Moldovan, D. Wang, Development of an 520 iron-amended biofilter for removal of arsenic from rural Canadian prairie potable water, 521 (2010) Retrieved from: http://www.mainstreamwater.com/Gottinger\%20et\%20al.pdf. (Acces $522 \quad 06.05 .2010)$.

523 [54] E. Sikora, D.D. Macdonald, The passivity of iron in the presence of 524 ethylenediaminetetraacetic acid I. General electrochemical behavior, J. Electrochem. Soc. 147 525 (2000) 4087-4092.

526 [55] P. Le Cloirec, C. Faur, Adsorption of organic compounds onto activated carbon 527 applications in water and air treatments, In Environmental Remediation T.J. Bandosz (editor). 528 Interf. Sci. Technol. 7 (2006) 375-419.

529 [56] T.L. Johnson, M.M. Scherer, P.G. Tratnyek, Kinetics of halogenated organic compound 530 degradation by iron metal, Environ. Sci. Technol. 30 (1996) 2634-2640.

531 [57] K.L. McGeough, R.M. Kalin, P. Myles, Carbon disulfide removal by zero valent iron, 532 Environ. Sci. Technol. 41 (2007) 4607-4612. 
533 [58] R.W. Gillham, Discussion of Papers/Discussion of nano-scale iron for dehalogenation.

534 by Evan K. Nyer and David B. Vance (2001), Ground Water Monit. Remed. 21, 41-54. 535 Ground Water Monit. Remed 23 (2003) 6-8.

536 [59] R.P. Batycky, H. Brenner, Thermal macrotransport processes in porous media. A review, 537 Adv. Water Resour. 20 (1997) 95-110.

538 [60] A.A. Shapiro, P.G. Bedrikovetsky, A stochastic theory for deep bed filtration accounting 539 for dispersion and size distributions, Physica A (2010) doi:10.1016/j.physa.2010.02.049.

540

541 
541 Table 1: Mass of material necessary to completely fill the hypothetical treatment units with 542 $100 \%$ metallic iron. The fundamental porosity of $\Phi_{0}=36 \%$ is assumed and the 543 value of $7,800 \mathrm{~kg} / \mathrm{m}^{3}$ is taken for the specific weight of $\mathrm{Fe}^{0}$.

\begin{tabular}{|c|c|c|c|c|}
\hline Unit & $\begin{array}{l}\mathbf{V}_{\text {unit }} \\
\left(\mathrm{m}^{3}\right)\end{array}$ & $\begin{array}{c}\mathbf{V}_{\mathbf{F e}} \\
\left(\mathrm{m}^{3}\right)\end{array}$ & $\begin{array}{c}\mathbf{V}_{\text {pores }} \\
\left(\mathrm{m}^{3}\right)\end{array}$ & $\begin{array}{l}\mathbf{m}_{\mathrm{Fe}} \\
(\mathrm{kg})\end{array}$ \\
\hline Filter & 0.004 & 0.0026 & 0.0014 & 20.08 \\
\hline Wall & 19.4 & 12.4 & 6.97 & 96,645 \\
\hline
\end{tabular}

544

545

546 
546 Table 2: Mass ( $\mathrm{m}_{\text {wall }}$ or $\mathrm{m}_{\mathrm{filter}}$ in $\mathrm{kg}$ ) of iron and weight proportion of consumed iron ( $\mathrm{P}$ in \%, same value for the wall or the filter) leading to porosity loss in the hypothetical field reactive wall and household filter as function of the nature of corrosion products. $\Phi_{\mathrm{r}}$ is the residual porosity (in this case $\Phi_{\mathrm{r}}=0$ and iron is not completely consumed, $\mathrm{P}<100 \%) . \mathrm{V}_{\text {oxid }} / \mathrm{V}_{\mathrm{Fe}}$ values are expansive coefficients from Ref. [15].

551

\begin{tabular}{|c|c|c|c|c|c|}
\hline Oxid & $\mathbf{V}_{\text {oxid }} / \mathbf{V}_{\mathrm{Fe}}$ & $\begin{array}{c}\mathbf{m}_{\text {wall }} \\
(\mathrm{kg})\end{array}$ & $\begin{array}{l}\mathbf{m}_{\text {filter }} \\
(\mathrm{kg})\end{array}$ & $\begin{array}{l}\mathbf{P} \\
(\%)\end{array}$ & $\begin{array}{l}\Phi_{\mathrm{r}} \\
(\%)\end{array}$ \\
\hline$\overline{1 / 2 \mathrm{Fe}_{2} \mathrm{O}_{3}}$ & 2.08 & 50,336 & 10.45 & 52.1 & 0 \\
\hline $1 / 3 \mathrm{Fe}_{3} \mathrm{O}_{4}$ & 2.12 & 48,538 & 10.08 & 50.2 & 0 \\
\hline$\gamma$-FeOOH & 3.03 & 26,779 & 5.56 & 27.7 & 0 \\
\hline$\beta-\mathrm{FeOOH}$ & 3.48 & 21,920 & 4.55 & 22.7 & 0 \\
\hline $\mathrm{Fe}(\mathrm{OH})_{2}$ & 3.75 & 19,768 & 4.11 & 20.5 & 0 \\
\hline$\alpha-\mathrm{FeOOH}$ & 3.91 & 18,681 & 3.88 & 19.3 & 0 \\
\hline $\mathrm{Fe}(\mathrm{OH})_{3}$ & 4.2 & 16,988 & 3.53 & 17.6 & 0 \\
\hline $\mathrm{Fe}(\mathrm{OH})_{3} \cdot 3 \mathrm{H}_{2} \mathrm{O}$ & 6.4 & 10,067 & 2.09 & 10.4 & 0 \\
\hline
\end{tabular}

552 
554

555

556

557

558

559

\begin{tabular}{lccc}
\hline Oxid & $\mathbf{V}_{\text {oxid }} / \mathbf{V}_{\mathbf{F e}}$ & $\mathbf{P}$ & $\Phi_{\mathbf{r}}$ \\
& & $(\%)$ & $(\%)$ \\
\hline $1 / 2 \mathrm{Fe}_{2} \mathrm{O}_{3}$ & 2.08 & 100 & 14.2 \\
$1 / 3 \mathrm{Fe}_{3} \mathrm{O}_{4}$ & 2.12 & 100 & 12.9 \\
$\gamma-\mathrm{FeOOH}$ & 3.03 & 75.1 & 0 \\
$\beta-\mathrm{FeOOH}$ & 3.48 & 61.5 & 0 \\
$\mathrm{Fe}(\mathrm{OH})_{2}$ & 3.75 & 55.5 & 0 \\
$\alpha-\mathrm{FeOOH}$ & 3.91 & 52.4 & 0 \\
$\mathrm{Fe}(\mathrm{OH})_{3}$ & 4.2 & 47.7 & 0 \\
$\mathrm{Fe}(\mathrm{OH})_{3} .3 \mathrm{H}_{2} \mathrm{O}$ & 6.4 & 28.2 & 0 \\
\hline
\end{tabular}
household filter. porosity $\Phi_{\mathrm{r}}$ (Eq. 4) as function of the nature of corrosion products for $\mathrm{Fe}^{0}$ :sandstone with a volumetric ratio 50:50. $\mathrm{V}_{\text {oxid }} / \mathrm{V}_{\mathrm{Fe}}$ values are expansive coefficient from Ref. [15]. The critical porosity of sandstone is $40 \%$ and its specific weight is $2.0 \mathrm{~kg} / \mathrm{m}^{3}$. The results are the same for the reactive wall and the

560

561

562 
563

564

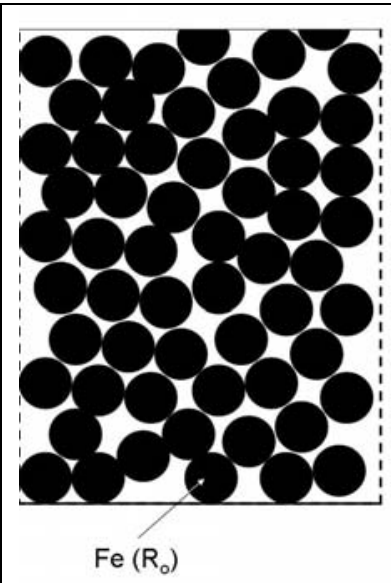

(a) volumetric ratio $\mathrm{Fe}^{0}$ :quartz 100:0

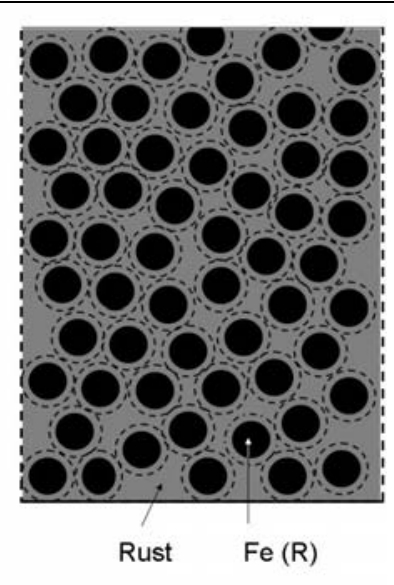

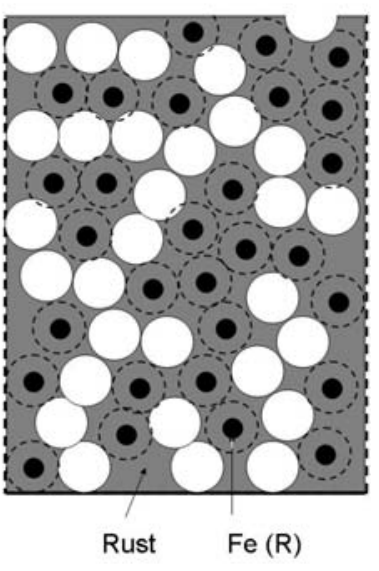

(b) volumetric ratio $\mathrm{Fe}^{0}$ :quartz 50:50

565

566

567 
568

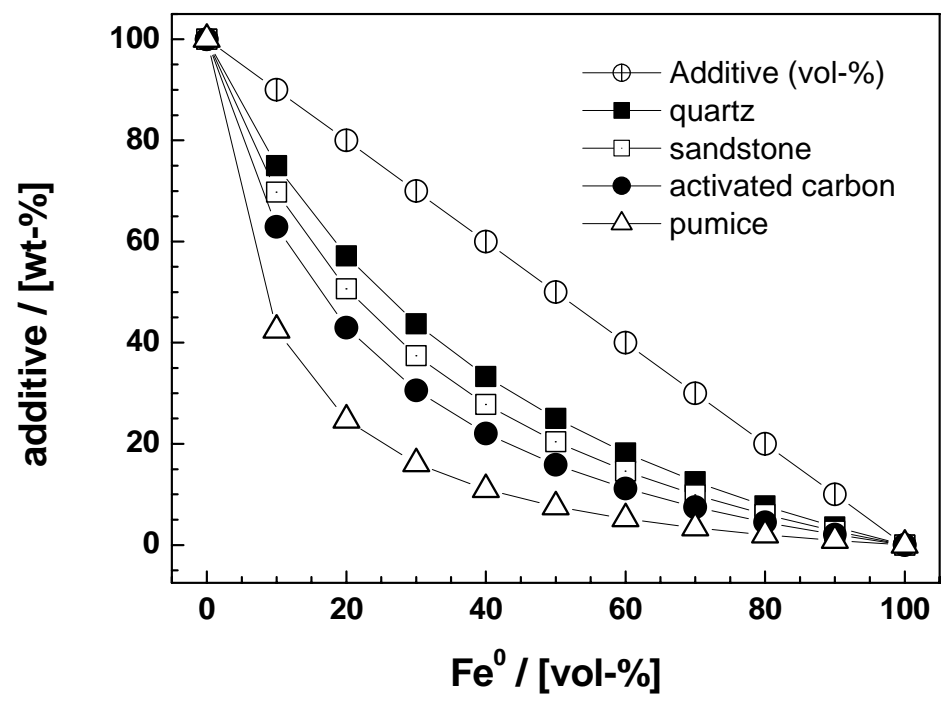

569

570

571

572

573 
$573 \quad$ Figure 3

574
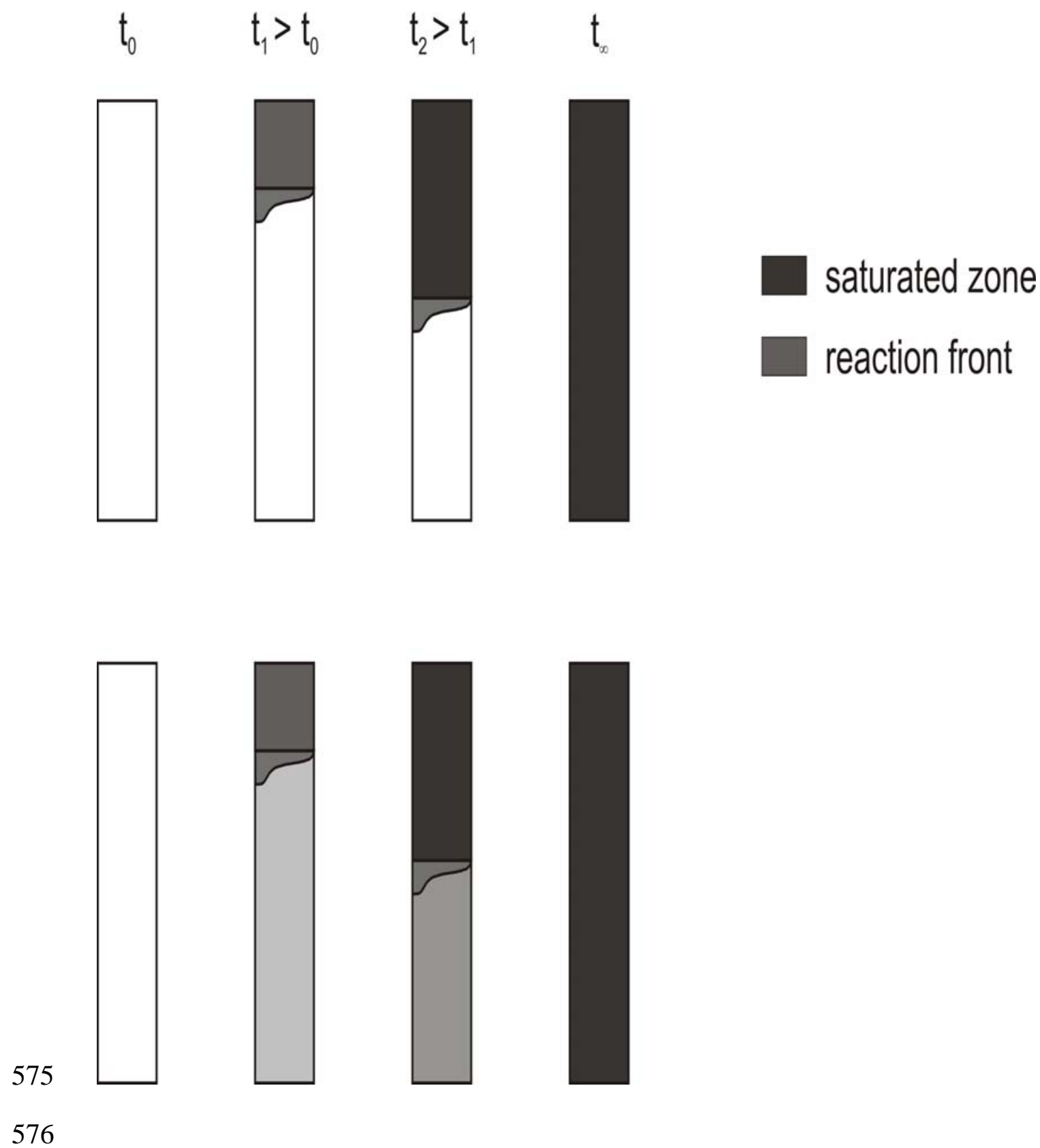


\section{Figure captions}

578 Figure 1: Schematic illustration of the impact of mixing $\mathrm{Fe}^{0}$ and quartz for the long-term 579 reactivity of $\mathrm{Fe}^{0}$ beds (clogging). When $\mathrm{Fe}^{0}$ is mixed with quartz more iron corrodes and the 580 initial porosity if progressively filled with porous iron oxides for water multi-filtration.

582 Figure 2: Variation of the weight percent of additive materials as function of the $\mathrm{Fe}^{0}$ 583 volumetric ratio. Due to the differences in density, there is no linear dependence. The depicted 584 variation of the wt-ratio depends on the material density. Used density values are: $\mathrm{Fe}^{0}: 7.80$ $585 \mathrm{~g} / \mathrm{cm}^{3}$, quartz: $2.65 \mathrm{~g} / \mathrm{cm}^{3}$, sandstone: $2.00 \mathrm{~g} / \mathrm{cm}^{3}$, activated carbon: $1.47 \mathrm{~g} / \mathrm{cm}^{3}$, and pumice $5860.64 \mathrm{~g} / \mathrm{cm}^{3}$.

587

588 Figure 3: Comparison of the evolution of contaminant loading in granular activated carbon

589 (GAC - up) and $\mathrm{Fe}^{0}$ (down) filters. The evolution of the GAC filters is virgin - preloaded 590 (reaction front) and saturated carbon. For the $\mathrm{Fe}^{0}$ filters a reaction front may exist due to 591 increased $\mathrm{O}_{2}$ in the influent but iron corrosion by $\mathrm{H}_{2} \mathrm{O}\left(\right.$ or $\mathrm{H}^{+}$) occurs uniformly in the whole 592 column. The light grey shadow indicates progressive $\mathrm{Fe}^{0}$ corrosion by water. 